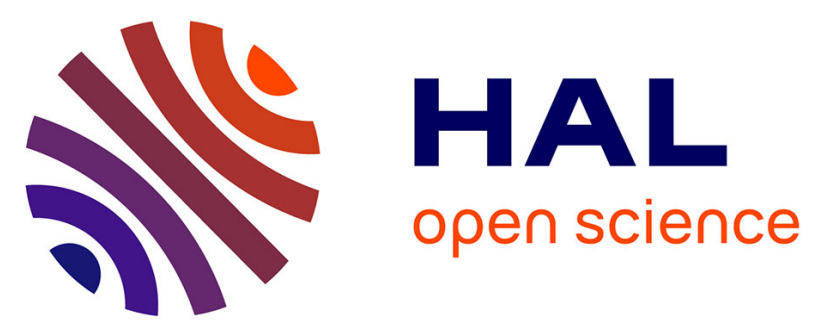

\title{
Contribution of atmospheric emissions to the contamination of leaf vegetables by persistent organic pollutants (POPs): Application to southeastern France
}

\author{
Solen Quéquiner, L. Musson, Yelva Roustan, P. Ciffroy
}

\section{- To cite this version:}

Solen Quéquiner, L. Musson, Yelva Roustan, P. Ciffroy. Contribution of atmospheric emissions to the contamination of leaf vegetables by persistent organic pollutants (POPs): Application to southeastern France. Atmospheric environment, 2009, 44 (7), pp.958-967. 10.1016/j.atmosenv.2009.11.012 . hal00589288

\section{HAL Id: hal-00589288 \\ https: / hal-enpc.archives-ouvertes.fr/hal-00589288}

Submitted on 8 Feb 2018

HAL is a multi-disciplinary open access archive for the deposit and dissemination of scientific research documents, whether they are published or not. The documents may come from teaching and research institutions in France or abroad, or from public or private research centers.
L'archive ouverte pluridisciplinaire HAL, est destinée au dépôt et à la diffusion de documents scientifiques de niveau recherche, publiés ou non, émanant des établissements d'enseignement et de recherche français ou étrangers, des laboratoires publics ou privés. 


\title{
Contribution of atmospheric emissions to the contamination of leaf vegetables by persistent organic pollutants (POPs): Application to Southeastern France
}

\author{
Solen Quéguiner ${ }^{\mathrm{a}}$, Luc Musson Genon ${ }^{\mathrm{a}, *}$, Yelva Roustan ${ }^{\mathrm{a}}$, Philippe Ciffroy ${ }^{\mathrm{b}}$ \\ ${ }^{a}$ Cerea, Joint laboratory École des Ponts ParisTech/EDF RED, Université Paris-Est, 6-8 avenue Blaise Pascal, 77455 Marne la Vallée Cedex 2, France \\ ${ }^{\mathrm{b}}$ Laboratoire National d'Hydraulique et Environnement, EDF RED, 6 quai Watier 78401 Chatou Cedex, France
}

\section{A R T I C L E I N F O}

\section{Article history:}

Received 2 July 2009

Received in revised form

2 November 2009

Accepted 5 November 2009

\section{Keywords:}

Persistent organic pollutant

Atmospheric pollution

Multi-media modeling

Leaf vegetable contamination

Benzo(a)pyrene

\begin{abstract}
A B S T R A C T
A modeling approach has been developed to estimate the contribution of atmospheric emissions to the contamination of leaf vegetables by persistent organic pollutants (POPs). It combines an Eulerian chemical transport model for atmospheric processes (Polair3D/Polyphemus) with a fate and transport model for soil and vegetation (Ourson). These two models were specifically adapted for POPs. Results are presented for benzo(a)pyrene (BaP). As expected no accumulation of BaP in leaf vegetables appears during the growth period for each harvest over the 10 years simulated. For BaP and leaf vegetables, this contamination depends primarily on direct atmospheric deposition without chemical transfer from the soil to the plant. These modeling results are compared to available data.
\end{abstract}

(c) 2009 Elsevier Ltd. All rights reserved.

\section{Introduction}

POPs tend to bioaccumulate in the food chain due to their long chemical half life and their lipophilic characteristics (Jones and de Voogt, 1999). POPs, as defined in the Stockholm Convention, include a large number of compounds, which are generally grouped by categories including the following: polycyclic aromatic hydrocarbons (PAH), polychlorinated dibenzo-p-dioxins and polychlorinated dibenzofurans (PCDD/F), polychlorobiphenyl compounds (PCB), hexachlorobenzene and various pesticides. After their emissions to the atmosphere, these pollutants are deposited to the Earth's surface by dry and wet deposition. They are then absorbed by soil and vegetation, as well as partially dissolved in surface waters. Following deposition, they can be reemitted to the atmosphere due to their long chemical half life (at least several months in soil and water) and their temperaturedependent volatility. This behavior, generally referred to as the grasshopper effect (Wania and Mackay, 1993), leads to their longrange transport over long timescales and those compounds have been found in remote areas such as the North Pole (AMAP, 1998; Wania and Mackay, 1996). Therefore, a better understanding of the exposure of the population to those pollutants requires

\footnotetext{
* Corresponding author at: EDF R\&D, MFEE/CEREA, 6 Quai Watier, 78401 Chatou Cedex, France. Tel.: +331308781 18; fax: +3313087 7108 .

E-mail address: luc.musson-genon@edf.fr (L. Musson Genon).
}

a comprehensive multi-media description of the complex processes that govern their fate and transport in the environment (Strand and Hov, 1996). Accordingly, it is desirable to simulate the fate and transport of those pollutants across several media including the atmosphere, soil and the food chain. Although 3Dmodeling is now largely used (Wania and Mackay, 1993; Van Jaarsveld et al., 1997; Hansen et al., 2004), the coupling of atmospheric chemical transport models and multi-media models (including soil and vegetation for example) has been limited so far and has typically involved applications to individual atmospheric point sources using Gaussian atmospheric dispersion models (Constantinou and Seigneur, 1993; EPA, 1998). We present here a modeling approach that combines a comprehensive atmospheric chemical transport model (Polair3D/Polyphemus) that simulates air pollution at European scale and a multi-media model (Ourson) that simulates the fate and transport of chemicals in soil and vegetation (including fruits and vegetables) applied at a regional scale. This approach has been previously used for heavy metals (Quéguiner et al., 2009) and we present here in detail the models developed for POPs.

The fate and transport of different POPs was simulated with this modeling system: benzo(a)pyrene (BaP), 2-4-4-trichlorobiphenyl (PCB28) and $\gamma$-hexachlorocyclohexane (lindane) (Quéguiner, 2008). Here, we restrict our presentation to $\mathrm{BaP}$ because it is one of the most commonly simulated POPs and monitoring data from the EMEP network are available for model evaluation. 


\section{Atmospheric modeling of POPs}

POPs can be re-emitted by the Earth's surface and it is, therefore, imperative to (1) simulate the interface between the atmosphere and soil with sufficient detail to correctly represent this important process and (2) simulate the atmospheric transport from a large number of sources and over long distances. An Eulerian modeling approach is, therefore, more appropriate than a Gaussian puff modeling approach because the former can treat a large number of sources and cover a large modeling domain, whereas Gaussian plume modeling becomes cumbersome as the number of sources modeled increases significantly and such models are typically limited to impacts within $50 \mathrm{~km}$ of the source. As a matter of fact, Eulerian atmospheric modeling coupled with a soil model is the modeling approach recommended by EMEP, the European organization that is responsible for environmental regulatory modeling (Gusev et al., 2005).

Furthermore, it is necessary to treat the atmospheric pollutants in the gas-phase and the particulate phase since POPs partition between these two phases and various atmospheric processes (wet scavenging, dry deposition, and chemical oxidation) depend on that phase partitioning. Accordingly, the Polair3D model of the Polyphemus modeling system was selected for this work. This model has already been evaluated satisfactorily for ozone (Mallet et al., 2007) and particulate matter (Sartelet et al., 2007). We added a land/surface water module to take into account the ability of POPs to be re-emitted to the atmosphere after atmospheric deposition to a soil compartment.

\subsection{Polair3D}

Polair3D, which is described in detail by Mallet et al. (2007), simulates the emissions, transport, dispersion, chemical transformation, wet deposition and dry deposition of gaseous and particulate-bound chemicals in the atmosphere. The modifications made to Polair3D to treat POPs (here BaP) are described below.

\subsection{Gas/particle partitioning and particle size distribution}

Except for primary particles (which are emitted directly as particles in the atmosphere), the partitioning of POPs between the gas and particle phases occurs mostly on existing particles. One must then describe the adsorption process on the particle surface (Junge, 1977). Assuming that the gas and particulate phases are at equilibrium, the fraction of a chemical that is adsorbed by particles can be expressed as follows:

$\varphi=\frac{\alpha \theta}{P_{\mathrm{s}}+\alpha \theta}$

where $\alpha=0.17$ (Pa $\mathrm{m}$ ) is a constant that depends on the molecular weight of the chemicals considered and $\theta=1.5 \times 10^{-4}\left(\mathrm{~m}^{2} \mathrm{~m}^{-3}\right.$ air $)$ is the specific surface area of the particle. The selected values correspond to values for background atmospheric conditions (Junge, 1977; Whitby, 1978). $P_{\mathrm{S}}(\mathrm{Pa})$ is the saturation vapor pressure of the chemical considered (Hincley et al., 1990). The values selected for BaP is provided in Table 1 .

This approach based on adsorption has been preferred to the more physically-sound absorption approach suggested by Falconer and Harner (2000) for its simplicity and the difficulty associated with obtaining well-documented data on aerosol concentrations and the organic fraction of atmospheric particulate matter. In fact, a comparative study conducted by Shatalov et al. (2005) gives similar results for both methods.
Table 1

Physico-chemical parameters used in POP modeling for BaP. $a_{\mathrm{p}}$ is the enthalpy of vaporization divided by $R$ (ideal gas law constant), $a_{\mathrm{H}}$ is the enthalpy of solution divided by $R$ and $a_{\mathrm{K}}$ the enthalpy of phase change divided by $R$.

\begin{tabular}{ll}
\hline Parameter & BaP \\
\hline Saturation vapor pressure: & $9.34 \times 10^{-7}, 11488$ \\
$\quad P_{\mathrm{s}}=P_{\mathrm{s}}^{0} \exp \left(-a_{\mathrm{p}}\left(\frac{1}{T}-\frac{1}{283.15}\right)\right) ; P_{\mathrm{s}}^{0}(\mathrm{~Pa}), a_{\mathrm{p}}(\mathrm{K})$ & $5 \times 10^{-11}$ \\
Decay constants: & $1.4 \times 10^{-5}$, \\
$\quad K_{\mathrm{OH}}\left(\mathrm{cm}^{3}\right.$ molecule $\left.{ }^{-1} \mathrm{~s}^{-1}\right)$ & $1.13 \times 10^{-8}$, \\
$\quad k_{\mathrm{aer}}^{\text {air }}\left(\mathrm{s}^{-1}\right), k_{\mathrm{dg}}^{\mathrm{s}}\left(\mathrm{s}^{-1}\right), k_{\mathrm{dg}}^{\text {sea }}\left(\mathrm{s}^{-1}\right)$ & $1.13 \times 10^{-7}$ \\
& $5.44 \times 10^{-2}, 7866$ \\
& \\
Henry's law constants: & $5.44 \times 10^{-6}$, \\
$\quad H_{\mathrm{i}}=H_{\mathrm{i}}^{0} \exp \left(-a_{\mathrm{H}}\left(\frac{1}{T}-\frac{1}{283.15}\right)\right) ; H_{\mathrm{i}}^{0}\left(\mathrm{~Pa} \mathrm{~m}^{3} \mathrm{~mol}^{-1}\right), a_{\mathrm{H}}(\mathrm{K})$ \\
Diffusion coefficients: $D_{\mathrm{gaz}}^{\text {air }}\left(\mathrm{cm}^{2} \mathrm{~s}^{-1}\right), D_{\mathrm{gaz}}^{\text {eau }}\left(\mathrm{cm}^{2} \mathrm{~s}^{-1}\right)$ & $6.24 \times 10^{-10}$, \\
$\quad$ Kinematic viscosity of air: $\nu_{\text {air }}\left(\mathrm{cm}^{2} \mathrm{~s}^{-1}\right)$ & 0.15 \\
$\quad$ & $4.99 \times 10^{10}, 7866$ \\
Octanol-air partitioning coefficients: & \\
$\quad K_{\mathrm{oa}}=K_{\mathrm{oa}}^{0} \exp \left(a_{\mathrm{K}}\left(\frac{1}{T}-\frac{1}{283.15}\right)\right) ; K_{\mathrm{oa}}^{0}, a_{\mathrm{K}}(\mathrm{K})$ & $1.1 \times 10^{6}$ \\
Octanol-water partitioning coefficients: $K_{\mathrm{ow}}\left(\mathrm{m}^{3} \mathrm{~kg}^{-1}\right)$ & 222.8 \\
$\quad$ Molar volume: $V_{\mathrm{m}}\left(\mathrm{cm}^{3} \mathrm{~mol}^{-1}\right)$ & \\
\hline
\end{tabular}

Due to a lack of information on the size distribution of existing particles on which BaP is adsorbed and the computational cost associated with a detailed representation of size-distributed gas-particle interactions, particle-bound POPs were represented with mono-dispersed particles of a representative median diameter of $0.84 \mu \mathrm{m}$ (Gusev et al., 2005).

\subsection{Atmospheric chemical transformations}

Due to a lack of knowledge of the chemical reactions associated with BaP, its chemical transformation is represented by a simple first-order decay that differs for the gas-phase and the particulate phase. These decay terms are characterized by decay constants, $k_{\text {gas }}^{\text {air }}$ and $k_{\mathrm{aer}}^{\text {air }}\left(\mathrm{s}^{-1}\right)$, for the gas and particulate phases, respectively.

Decay in the gas-phase may result from photolysis, reaction with hydroxyl radicals $(\mathrm{OH})$, nitrate radicals $\left(\mathrm{NO}_{3}\right)$, ozone $\left(\mathrm{O}_{3}\right)$ and in urban areas nitric acid $\left(\mathrm{HNO}_{3}\right)$. The $\mathrm{OH}$ reaction seems to dominate (Atkinson et al., 1999). Therefore, we selected $k_{\text {gas }}^{\text {air }}=k_{\mathrm{OH}}$ $[\mathrm{OH}]$ where $[\mathrm{OH}]$ is the $\mathrm{OH}$ concentration (molecule $\mathrm{cm}^{-3}$ ) and $k_{\mathrm{OH}}$ is the kinetic constant $\left(\mathrm{cm}^{3}\right.$ molecule $\left.{ }^{-1} \mathrm{~s}^{-1}\right)$ given in Table 1 (Brubaker and Hites, 1998). Its diurnal variation is prescribed on a monthly basis following the $1996 \mathrm{EMEP} / \mathrm{MSC}-\mathrm{W}$ report. Due to a lack of data, decay due to photo-degradation in the particulate phase was modeled using a constant empirical value proposed by Chen et al. (2001) for BaP (Table 1).

\subsection{Wet scavenging}

Wet scavenging by precipitation is described in detail by Roustan (2005). It is modeled using scavenging coefficients that differ for the gaseous and particle-bound chemicals. For the particle phase, the scavenging coefficient $\lambda_{\mathrm{a}}\left(\mathrm{s}^{-1}\right)$ depends on cloud life time $\tau_{\mathrm{c}}(\mathrm{s})$ and raining time $\tau_{\mathrm{r}}(\mathrm{s})$ characterizing rain intensity following (Roselle and Binkowski, 1999): $\lambda_{\mathrm{a}}=\left(\exp \left(-\tau_{\mathrm{c}}\right)\right.$ $\left.\left.\tau_{\mathrm{r}}\right)-1\right) / \tau_{\mathrm{c}}$.

For the gas-phase, the scavenging coefficient $\lambda_{\mathrm{g}}\left(\mathrm{s}^{-1}\right)$ depends on the air water partition coefficient, $K_{\mathrm{aw}}$, which depends on the standard Henry's law constant $\mathrm{H}$ as follows: $K_{\mathrm{aw}}=H / R T$, (the Henry's law constant $H$ is provided in Table 1, Hulscher et al. (1992)) and cloud liquid water content $q_{\mathrm{c}}\left(\mathrm{kg}\right.$ water $\mathrm{kg}^{-1}$ air $): \lambda_{\mathrm{g}}=\lambda_{\mathrm{c}}\left(q_{\mathrm{c}} K_{\mathrm{aw}} /\right.$ $\left.\left(1+q_{\mathrm{c}} K_{\mathrm{aw}}\right)\right)$. Thus the overall scavenging coefficient for both gas and particles is: $\lambda=\varphi \lambda_{\mathrm{a}}+(1-\varphi) \lambda_{\mathrm{g}}$. 


\subsection{Interactions with the Earth's surface}

For POPs, the Earth's surface acts both as a sink for gases and particles and as a source for gases, since POPs can be re-emitted in gaseous form (e.g., due to an increase in temperature that would increase their volatility). The net result of those atmosphere/ surface exchange processes is expressed in the atmospheric model as a diffusion flux term for the model surface layer.

\section{Modeling of the Earth's surface}

Modeling of the Earth's surface for POPs is essential because of the need to simulate the re-emission of some of those compounds. The modeling of this top soil layer in the model is described below. The model formulation differs depending on the type of surface and we present such formulations for various land types (bare, forested, grazing and cultivated) as well as surface water.

\subsection{Modeling of bare land}

Bare land is land without any type of vegetation. It consists of a mixture of inorganic and organic matter, water and air. A top soil layer with a standard thickness $z_{\mathrm{s}}$ of $0.15 \mathrm{~m}$ (Jury et al., 1983) is used to represent the layer that interacts with the atmosphere, as used in the DEHM-POP model (Hansen et al., 2004). The equation that governs the temporal evolution of the concentration of a chemical in that top soil layer $C^{s}\left(\mathrm{ng} \mathrm{m}^{-2}\right)$ is expressed as follows:

$\frac{\partial C^{\mathrm{s}}}{\partial t}=\frac{1}{z_{\mathrm{s}}}\left(F_{\mathrm{daer}}^{\mathrm{s}}+F_{\mathrm{dgaz}}^{\mathrm{s}}+F_{\mathrm{w}}\right)-\left(k_{\mathrm{em}}^{\mathrm{s}}+k_{\mathrm{vt}}^{\mathrm{s}}+k_{\mathrm{dg}}^{\mathrm{s}}\right) C^{\mathrm{s}}$

where $F_{\text {daer }}^{\mathrm{s}}$ is the dry deposition flux of the particle-bound chemical, $F_{\text {dgaz }}^{\mathrm{s}}$ is the dry deposition flux of the gaseous chemical,

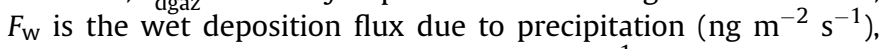
$k_{\mathrm{em}}^{\mathrm{s}}, k_{\mathrm{vt}}^{\mathrm{s}}$, and $k_{\mathrm{dg}}^{\mathrm{s}}$ are the kinetic constants $\left(\mathrm{s}^{-1}\right)$ corresponding to losses by re-emission to the atmosphere, downward vertical transport by percolation and chemical or biological decay, respectively. The value of $k_{\mathrm{dg}}^{\mathrm{s}}$ provided in Table 1 is from Mackay et al. (1992).

The dry deposition flux for the particle-bound chemicals is calculated with a dry deposition velocity $V_{\text {daer }}^{s}\left(\mathrm{~m} \mathrm{~s}^{-1}\right)$ as follows:

$F_{\text {daer }}^{\mathrm{s}}=V_{\text {daer }}^{\mathrm{s}} \varphi C$

where $C\left(\mathrm{ng} \mathrm{m}^{-3}\right)$ is the chemical concentration in the atmospheric surface layer and $\varphi$ is the particle-bound fraction calculated by Polair3D; $V_{\text {daer }}^{\mathrm{s}}=1 /\left(R_{\mathrm{a}}+R_{\mathrm{S}}\right)$ where $R_{\mathrm{a}}\left(\mathrm{s} \mathrm{m}^{-1}\right)$ is the aerodynamic resistance calculated according to Monin-Obukhov theory and $R_{\mathrm{S}}$ $\left(\mathrm{s} \mathrm{m}^{-1}\right)$ is the surface resistance for bare soil obtained according to Tsyro and Erdman (2000):

$R_{\mathrm{s}}^{-1}=0.0004 u_{*}^{2}+0.0002$ for $\mathrm{BaP}$ where $u^{*}$ is the friction velocity $\left(\mathrm{m} \mathrm{s}^{-1}\right)$ which depends on the roughness length for the bare soil. follows:

The dry deposition flux for gaseous chemicals is expressed as

$F_{\text {dgaz }}^{\mathrm{s}}=V_{\mathrm{dgaz}}^{\mathrm{s}}(1-\varphi) C$

$V_{\mathrm{dgaz}}^{\mathrm{s}}\left(\mathrm{m} \mathrm{s}^{-1}\right)$ is the dry deposition velocity for bare soil, which is expressed as follows:

$$
V_{\mathrm{dgaz}}^{\mathrm{s}}=\left(\left(D_{\mathrm{gaz}}^{\mathrm{air}} q_{\mathrm{air}}^{10 / 3}+D_{\mathrm{gaz}}^{\mathrm{w}} q_{\mathrm{w}}^{10 / 3} K_{\mathrm{aw}}\right)\left(1-q_{\mathrm{air}}-q_{\mathrm{w}}\right)^{-2}\right) /\left(z_{\mathrm{s}} / 2\right)
$$

where $D_{\text {gaz }}^{\text {air }}$ and $D_{\text {gaz }}^{\mathrm{w}}$ are the molecular diffusion coefficients in air and water, respectively (see Table 1 ), and $q_{\text {air }}$ and $q_{\mathrm{w}}$ are the air and water contents by volume of the soil, which are selected to be 0.2 and 0.3 , respectively (Jury et al., 1983).
The wet deposition flux is expressed as a function of the scavenging coefficient $\lambda\left(\mathrm{s}^{-1}\right)$ and chemical concentration in air $C$ as follows ( $\Delta z$ is the depth of the atmospheric layer below cloud base in $\mathrm{m})$.

$F_{\mathrm{W}}=\lambda C \Delta z$

The re-emission by volatilization depends on the exchange velocity $V_{\mathrm{dgaz}}^{\mathrm{s}}$. The re-emission rate constant is expressed as follows:

$k_{\mathrm{em}}^{\mathrm{s}}=\frac{V_{\mathrm{dgaz}}^{\mathrm{s}}}{z_{\mathrm{s}} K_{\mathrm{as}}}$

where $K_{\mathrm{as}}$ is the air/soil partitioning coefficient obtained from Strand and Hov (1996).

$K_{\mathrm{as}}=\rho_{\mathrm{sol}} f_{\mathrm{oc}} K_{\mathrm{oc}} K_{\mathrm{aw}}+q_{\mathrm{w}} K_{\mathrm{aw}}+q_{\mathrm{air}}$, where $\rho_{\mathrm{s}}=1350 \mathrm{~kg} \mathrm{~m}^{-3}$ is the soil density, $f_{\mathrm{oc}}=0.02$ is the organic carbon fraction, which is assumed to be constant for bare soil (Mackay and Paterson, 1991), $K_{\mathrm{oc}}=0.35 K_{\mathrm{ow}}\left(\mathrm{m}^{3} \mathrm{~kg}^{-1}\right)$ is the organic carbon/water partitioning coefficient, which is related to the octanol/water partitioning coefficient $K_{\text {ow }}$ (Table 1, Mackay et al., 1992) via a linear regression equation (Seth et al., 1999).

The rate constant governing the chemical loss due to vertical water transport is calculated as follows (Hansen et al., 2004):

$k_{\mathrm{vt}}^{\mathrm{sol} \_\mathrm{nu}}=\frac{P_{\mathrm{o}}}{z_{\mathrm{s}}} \frac{K_{\mathrm{aw}}}{K_{\mathrm{as}}}$

where $P_{\mathrm{o}}$ is the precipitation rate at the surface in $\mathrm{mm} \mathrm{s}^{-1}$.

\subsection{Modeling of the vegetation layer}

The interactions between vegetation and atmosphere occur directly at the foliar surface and indirectly from the soil contamination by the atmosphere via the root system. The atmosphere/ vegetation exchange depends on the vegetation cover: grass, cultivated land, deciduous and evergreen forests. The temporal evolution of the chemical concentration in the vegetation cover with a height $z_{\mathrm{veg}}(\mathrm{m})$ is expressed as follows:

$$
\begin{aligned}
\frac{\partial C^{\mathrm{veg}}}{\partial t}= & \frac{1}{z_{\mathrm{veg}}}\left(F_{\mathrm{daer}}^{\mathrm{veg}}+F_{\mathrm{dgaz}}^{\mathrm{veg}}+f_{\mathrm{veg}} F_{\mathrm{w}}\right) \\
& -\left(k_{\mathrm{em}}^{\mathrm{veg}}+k_{\mathrm{dg}}^{\mathrm{veg}}+k_{\mathrm{defol}}^{\mathrm{veg}}+k_{\mathrm{crop}}^{\mathrm{veg}}\right) C^{\mathrm{veg}}
\end{aligned}
$$

where $F_{\text {daer }}^{\mathrm{veg}}$ is the dry deposition flux for particle-bound chemicals, $F_{\text {dgaz }}^{\mathrm{veg}}$ is the dry deposition flux for gaseous chemicals $\left(\mathrm{ng} \mathrm{m}^{-2} \mathrm{~s}^{-1}\right)$, $f_{\mathrm{veg}}$ is the fraction of precipitation intercepted by vegetation, $k_{\mathrm{dg}}^{\mathrm{veg}}$ is the decay rate constant in vegetation, $k_{\mathrm{defol}}^{\mathrm{veg}}$ is the defoliation rate constant and $k_{\text {crop }}^{\mathrm{veg}}$ is the loss rate constant due to harvest $\left(\mathrm{s}^{-1}\right)$.

The dry deposition flux for particles is expressed as that for bare soil (see Equation (3)) except that a dry deposition velocity specific to a vegetation cover is used. It depends on the vegetation cover type; for grass and cultivated land, the formulation of Wesely et al. (1985) is used:

$V_{\text {daer }}^{\text {veg }}=R_{\text {grass }}^{-1}=0.002 u_{*}(1+(300 / \max (0,-L)))^{2 / 3}$ where $L$ is the Monin-Obukhov length $(\mathrm{m})$, atmospheric thermal stability parameter.

For evergreen forests, the formulation of Ruijgrok et al. (1997) is used: $R_{\text {forest }}^{-1}=E u_{*}^{2} / u_{\mathrm{h}}$ where $E=0.075 u_{*}^{0.3}$ (for BaP) is the collection coefficient for particles in the forest canopy, which depends on particle size and $u_{\mathrm{h}}\left(\mathrm{m} \mathrm{s}^{-1}\right)$ is the wind speed at canopy height. For deciduous forests, the formulation for evergreen forests is used from May to September and that for bare soil is used from October to April (with an appropriate roughness length). 
The dry deposition flux for gaseous chemicals is expressed as that for bare land (see Equation (4)) except that the exchange velocity is a function of three resistances to take into account the foliar exchange: $V_{\mathrm{dgaz}}^{\mathrm{veg}}=\left(R_{\mathrm{a}}+R_{\mathrm{b}}+R_{\mathrm{c}}\right)^{-1}$ in $\mathrm{m} \mathrm{s}^{-1}$ where $R_{\mathrm{b}}=2$ $(\kappa u *)^{-1}(S c / P r)^{2 / 3}\left(m^{-1} s\right)$ is the resistance of the quasi-laminar surface layer with $\kappa=0.4$ (von Karman constant), $P r=0.74$ (Prandtl number), and $S c=v_{\text {air }} / D_{\text {gaz }}^{\text {air }}$ where $\nu_{\text {air }}$ is given in Table 1 , and $R_{\mathrm{c}}$ $\left(\mathrm{m}^{-1} \mathrm{~s}\right)$ is the foliar resistance, which depends on the vegetation cover.

For grass and cultivated land, the formulation of McLachlan et al. (1995) is used; it relates the foliar resistance, approximated by the cuticular resistance, to the octanol/air partition coefficient, $K_{\text {oa }}$, as follows:

$\log \left(R_{\mathrm{C}}\right)=5.29 \log \left(V_{\mathrm{m}}\right)-1.43-\log \left(K_{\mathrm{oa}}\right)$ where $V_{\mathrm{m}}\left(\mathrm{m}^{3}\right)$ is the molar volume estimated from the POP molecular weight; it is given in Table 1.

For both types of forests, a similar approach leads to the following relationships (Horstmann and McLachlan, 1998):

$\log \left(V_{\text {dgaz }}^{\text {veg }}\right)=0.76 \log \left(K_{\mathrm{oa}}\right)-6.97$ for a deciduous forest and

$\log \left(V_{\text {dgaz }}^{\text {veg }}\right)=0.68 \log \left(K_{\text {oa }}\right)-7.39$ for an evergreen forest

These empirical formulations have been preferred to a more physical approach using explicit stomatal resistance (Riederer, 1990 ) that has given similar results in our simulations (Quéguiner, 2008).

The precipitation scavenging flux is weighted by the interception fraction of precipitation by the canopy, $f_{\mathrm{veg}}$. This fraction depends on the density and thickness of the canopy and, therefore, the vegetation type. The values of Wegmann et al. (2004) were used (see Table 2).

The re-emission rate constant due to volatilization is expressed as follows:

$k_{\mathrm{em}}^{\mathrm{veg}}=\frac{V_{\mathrm{dgaz}}^{\mathrm{veg}}}{z_{\mathrm{s}} K_{\mathrm{va}}}$

where $K_{\mathrm{va}}$ is the vegetation/air partition coefficient, which can be expressed as a function of the octanol/air coefficient (Horstmann and McLachlan, 1998; Thomas et al., 1998) as follows: $K_{\mathrm{va}}=m K_{\mathrm{oa}}^{\mathrm{n}}$ where $m$ and $n$ are constants that are plant specific (see Table 3 ).

There are many loss processes for chemicals in vegetation besides re-emission to the atmosphere, including chemical decay within the vegetation and losses due to defoliation and harvest. Decay processes for POPs have been identified but are poorly known. Thus a decay rate constant, $k_{\mathrm{dg}}^{\mathrm{veg}}\left(\mathrm{s}^{-1}\right)$, is used and the corresponding half life is 709 days (Mackay et al., 1992) for grass and cultivated land; for forests, it is defined as twice those for bare soil following Gusev et al. (2005).

By assuming, as is usual in atmospheric POPs modeling, that the vegetation biomass volume remains constant with time during the growth period and that the vegetation is either harvested or falls to the ground (defoliation), the loss coefficients, $k_{\text {crop }}^{\mathrm{veg}}$ and $k_{\text {defol }}^{\mathrm{veg}}\left(\mathrm{s}^{-1}\right)$ are expressed as follows:

Table 2

Fraction absorbed by vegetation during wet deposition.

\begin{tabular}{lc}
\hline Land type & $f_{\text {veg }}$ \\
\hline Grass & 0.068 \\
Cultivated land & 0.068 \\
Deciduous forest & 0.193 \\
Evergreen forest & 0.35 \\
\hline
\end{tabular}

Table 3

Coefficients used to relate the vegetation-air partitioning coefficient to the octanol-air partitioning coefficient.

\begin{tabular}{llll}
\hline Land type & $m$ & $n$ & References \\
\hline Grass & 22.91 & 0.445 & Thomas et al., 1998 \\
Cultivated land & 22.91 & 0.445 & Thomas et al., 1998 \\
Deciduous forest & 38 & 0.69 & Horstmann and McLachlan, 1998 \\
Evergreen forest & 14 & 0.76 & Horstmann and McLachlan, 1998 \\
\hline
\end{tabular}

$k_{\text {crop }}^{\mathrm{veg}}=E / T$ and $k_{\text {defol }}^{\mathrm{veg}}=(1-E) / T$ where $E$ is the harvest efficiency ( 0.59 for grass and cultivated land according to Severinsen and Jager (1998); 0 for forests) and $T$ (s) is the foliar residence time, which depends on the vegetation type (see Table 4).

\subsection{Modeling of surface water}

The transport of POPs by oceans is an important process that redistributes those chemicals at the global scale and would require the simulation of 3-D ocean dynamics. Nevertheless, at the regional scale, we take into account this reservoir as static to simulate the exchange between the atmosphere and the ocean surface near the border of the modeling domain. Thus, without oceanic transport, the equation governing the POP concentrations in the ocean surface layer with a thickness $z_{\text {sea }}=75 \mathrm{~m}$, can be written as follows:

$\frac{\partial C^{\text {sea }}}{\partial t}=\frac{1}{z_{\text {sea }}}\left(F_{\text {daer }}^{\text {sea }}+F_{\text {dgaz }}^{\text {sea }}+F_{\mathrm{w}}\right)-\left(k_{\text {em }}^{\text {sea }}+k_{\mathrm{dg}}^{\text {sea }}\right) C^{\text {sea }}$

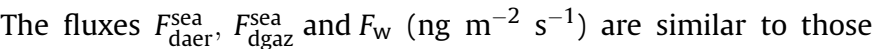
for bare land (Equation (2)), except that the surface resistance for particle deposition depends on the surface state through the friction velocity $u *: \quad V_{\text {dgaz }}^{\text {sea }}=R_{\text {sea }}^{-1}=\left(0.15 u_{*}^{2}+0.013\right)$ in $\mathrm{m} \mathrm{s}^{-1}$ for BaP. The dry deposition flux for gaseous chemicals is also expressed in terms of a resistance that includes an exchange velocity for sea water, $V_{\mathrm{dgaz}}^{\text {sea }}\left(\mathrm{m} \mathrm{s}^{-1}\right)$, which depends on the air and water resistances according to Schwarzenbach et al. (1993): $\left(V_{\mathrm{dgaz}}^{\text {sea }}\right)^{-1}=k_{1}^{-1}+\left(k_{\mathrm{g}} K_{\mathrm{wa}}\right)^{-1}$ where $k_{\mathrm{l}}=\left(4 \cdot 10^{-4}+\right.$ $\left.4 \cdot 10^{-5} u^{2}\right)\left(D_{\text {gaz }}^{\mathrm{w}} / D_{\mathrm{g}}^{\mathrm{w}}\left(\mathrm{O}_{2}\right)\right)^{0.57} \cdot 10^{-2}$ and $k_{\mathrm{g}}=(0.3+0.2 u)$ $\left(D_{\text {gaz }}^{\text {air }} / D_{\mathrm{g}}^{\text {air }}\left(\mathrm{H}_{2} \mathrm{O}\right)\right)^{0.61} \cdot 10^{-2}$ where $u\left(\mathrm{~m} \mathrm{~s}^{-1}\right)$ is the wind speed, $D_{\text {gaz }}^{\mathrm{w}}$ and $D_{\text {gaz }}^{\text {air }}$ are the diffusion coefficients $\left(\mathrm{cm}^{2} \mathrm{~s}^{-1}\right)$ of the chemicals in water and air, $D_{\mathrm{g}}^{\mathrm{w}}\left(\mathrm{O}_{2}\right)$ that of oxygen in water, $D_{\mathrm{g}}^{\text {air }}\left(\mathrm{H}_{2} \mathrm{O}\right)$ that of water in air.

For re-emission from the sea to the atmosphere, the rate constant in $\mathrm{s}^{-1}$ is expressed as follows:

$k_{\mathrm{em}}^{\text {sea }}=\frac{V_{\mathrm{dgaz}}^{\mathrm{sea}}}{z_{\mathrm{sea}} K_{\mathrm{wa}}}$

Loss of chemicals at the surface of the ocean occurs via vertical and horizontal transport, hydrolysis and photolysis. These complex phenomena require a 3-D modeling approach for the ocean. Here, a simpler approach based on a loss rate constant, $k_{\mathrm{dg}}^{\text {sea }}\left(\mathrm{s}^{-1}\right)$, which lumps all these phenomena is used (Mackay et al., 1992, Table 1).

Table 4

Residence time in vegetation.

\begin{tabular}{lcl}
\hline Land type & Foliar residence time (days) & References \\
\hline Grass & 406 & Wegmann et al., 2004 \\
Cultivated land & 91 & Severinsen and Jager, 1998 \\
Deciduous forest & 406 & Wegmann et al., 2004 \\
Evergreen forest & 1825 & Wania and McLachlan, 2001 \\
\hline
\end{tabular}


Note that we do not differentiate between sea and freshwater surfaces and that urban land is treated similarly to bare land. Given that the spatial resolution is $1.125^{\circ}$ for this European modeling study, such approximations should have negligible effects due to the small extent of this type area in a mesh.

The model described here is, therefore, a compromise between parameterizations already available in the air quality model Polair3D/Polyphemus and those available in the literature for POPs (particularly those of the DEHM-POP and EMEP/MSCE models).

\section{Atmospheric simulations}

The atmospheric simulations have been performed over four years, 2001-2004. The meteorological inputs were obtained over the European domain from the European Centre for Mediumrange Weather Forecasting (ECMWF) for the year 2001. The BaP emission inventory (shown in Fig. 1) was obtained from the EMEP inventories with the same vertical distribution (only $10 \%$ of $\mathrm{BaP}$ are emitted from elevated sources), sources, gas-particle partition and temporal distribution. The temporal variation of emissions follows that of industrial combustion source activities for BaP (larger emissions occur in winter due to increased residential heating).

Boundary conditions are obtained from simulations conducted earlier with the EMEP/MSCE-POP model. For the first simulated year, 2001, initial concentrations in the land compartment are taken as zero. A sensitivity test with this initial condition has shown a negligible effect, during the four years simulated, on the air concentration that will be used for cultivated soil modeling. The land use and land cover data were obtained from the RDM model with 14 land use categories, which were grouped into the six categories used here: bare land, grass, cultivated land, deciduous forests, evergreen forests and water. The corresponding land characteristics (roughness length and canopy height) are presented in Table 5.
Table 5

Roughness length $z_{0}$ and vegetal cover height $d_{0}$ for different land types. Winter is taken to be from November to February, spring from March to April, summer from May to August and fall from September to October. The snow season corresponds to a snow cover of $1 \mathrm{~cm}$. These values are from Brook et al. (1999).

\begin{tabular}{lllllll}
\hline$z_{0}, d_{0}$ & $\begin{array}{l}\text { Bare land/ } \\
\text { urban area }\end{array}$ & $\begin{array}{l}\text { Evergreen } \\
\text { forest }\end{array}$ & $\begin{array}{l}\text { Deciduous } \\
\text { forest }\end{array}$ & Grass & \multicolumn{2}{l}{$\begin{array}{l}\text { Cultivated } \\
\text { land }\end{array}$} \\
\hline Winter & $2.0,0.0$ & $1.57,5.67$ & $0.875,5.0$ & $0.05,0.00$ & $0.32,0.30$ & $0.0055,0.0$ \\
Spring & $2.0,0.0$ & $1.57,6.67$ & $0.675,6.0$ & $0.05,0.30$ & $0.22,0.75$ & $0.0055,0.0$ \\
Summer & $2.0,0.0$ & $1.53,8.0$ & $0.950,8.0$ & $0.05,0.55$ & $0.50,1.25$ & $0.0055,0.0$ \\
Fall & $2.0,0.0$ & $1.57,8.0$ & $0.975,8.0$ & $0.05,0.55$ & $0.50,1.25$ & $0.0055,0.0$ \\
Snow & $2.0,0.0$ & $1.58,5.67$ & $0.550,5.0$ & $0.05,0.00$ & $0.15,0.30$ & $0.0055,0.0$ \\
\hline
\end{tabular}

In order to obtain the European contribution to regional impact on cultivated vegetables studied later, the atmospheric model was applied over Europe with a spatial resolution of $1.125^{\circ}$.

The atmospheric simulation results were compared with the few available measurements available from the EMEP monitoring network for 2001 (Quéguiner, 2008). Here, only a comparison with the results of an earlier simulation conducted with the EMEP/MSCE model is presented because this EMEP/MSCE had been successfully evaluated against EMEP measurements over a multi-year period and, therefore, can be considered to be a valuable reference (Gusev et al., 2005).

Those comparisons are presented for BaP in Fig. 2 for the atmospheric concentrations and performance statistics are presented in Table 6. The concentration fields are similar, which results in spatial correlation coefficients of high values for BaP (Table 6). Polair3D tends to slightly overestimate the BaP concentrations over western Europe.

\section{Modeling of POPs in harvested leaf vegetables}

\subsection{Modeling of cultivated land}

Our approach follows that used by Quéguiner et al. (2009) and was adapted here for POPs, using the work of Legind and Trapp (2009).
BaP emission in 2001, g.km². .ear $^{-1}$

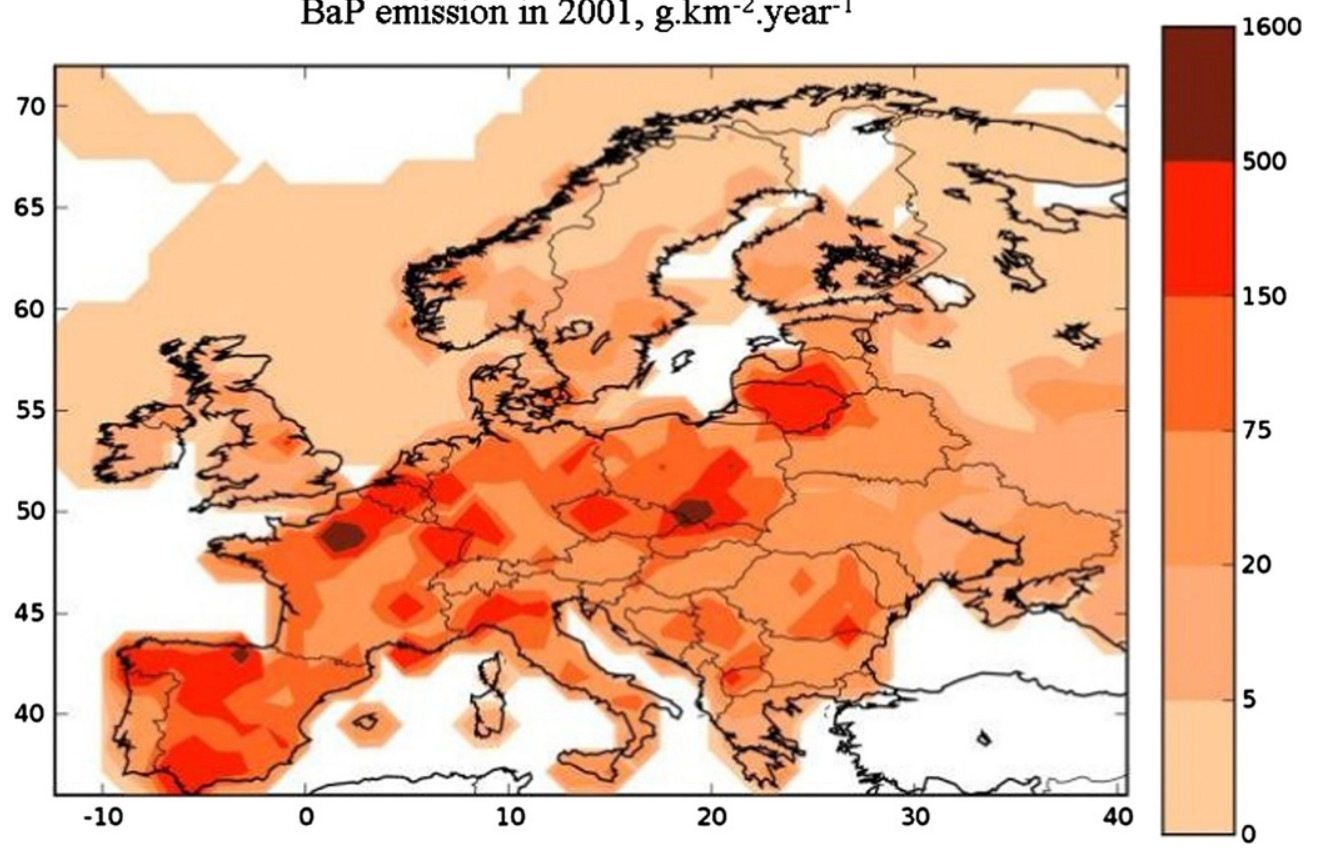

Fig. 1. Spatial distribution of BaP emissions in $\mathrm{g} \mathrm{km}^{-2}$ year ${ }^{-1}$. 
a

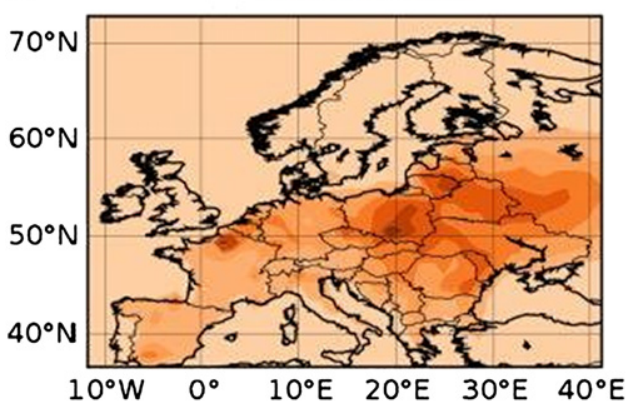

C

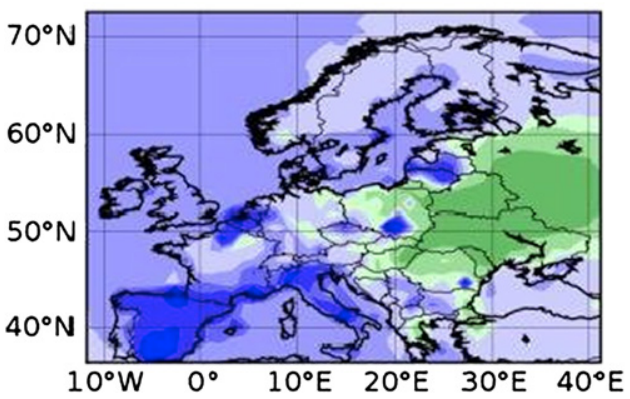

b

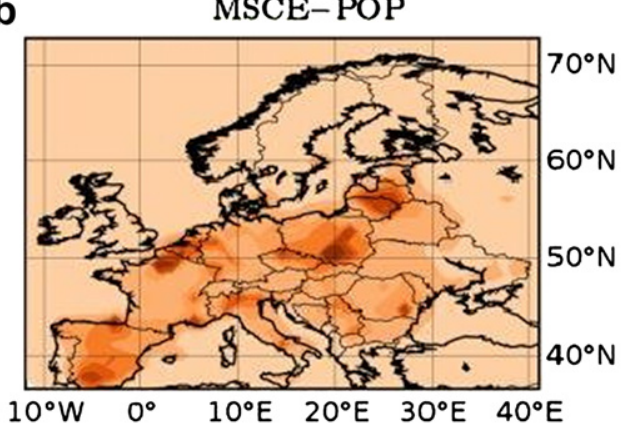

(a) and (b) Concentration in ng. $\mathrm{m}^{-3}$

$\begin{array}{lllllll}0.3 & 0.6 & 0.9 & 1.2 & 1.6 & 2.4 & 5.6\end{array}$

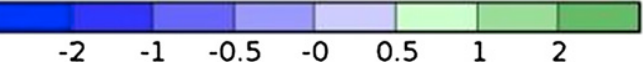

(c) Fractional bias

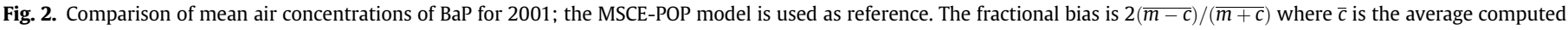
value and $\bar{m}$ the average reference (EMEP) value.

The equation that governs the chemical concentrations in cultivated soil is similar to that for bare soil and is expressed as follows ( $C^{\mathrm{sc}}$ is expressed here in $\mathrm{ng} \mathrm{kg}^{-1}$ or pptw):

$$
\frac{\partial C^{\mathrm{sc}}}{\partial t}=\frac{\left(1-f_{\mathrm{veg}}\right)}{z_{\mathrm{sc}} \rho_{\mathrm{sc}}}\left(F_{\mathrm{daer}}^{\mathrm{sc}}+F_{\mathrm{dgaz}}^{\mathrm{sc}}+F_{\mathrm{w}}\right)-\left(k_{\mathrm{em}}^{\mathrm{sc}}+k_{\mathrm{vt}}^{\mathrm{sc}}+k_{\mathrm{dg}}^{\mathrm{sc}}\right) C^{\mathrm{sc}}
$$

where $z_{\mathrm{sc}}$ is the depth of the cultivated soil layer (m), which is taken to be equal to the root depth and $\rho_{\mathrm{sc}}\left(\mathrm{kg} \mathrm{m}^{-3}\right)$ is the soil density. The atmospheric loading is reduced compared to that to bare soil by the fraction that is retained by the vegetation cover. Thus, the atmospheric fluxes $F_{\text {daer }}^{\text {sc }}, F_{\text {daer }}^{\text {sc }}$ and $F_{\text {daer }}^{\text {sc }}\left(\mathrm{ng} \mathrm{m}^{-2} \mathrm{~s}^{-1}\right)$ and the loss rate coefficients $k_{\mathrm{em}}^{\mathrm{sc}}$ and $k_{\mathrm{dg}}^{\mathrm{sc}}\left(\mathrm{s}^{-1}\right)$ are identical to those of Equation (2). The percolation term that represents vertical transport by interstitial water was modified to better describe the mass transfer between the soil and the vegetation following (Ciffroy et al., 2006). This term can be written as follows: $k_{\mathrm{vt}}^{\mathrm{sc}}=v_{\mathrm{p}} /\left(z_{\mathrm{sc}}\left(q_{\mathrm{l}}+\rho_{\mathrm{sc}} f_{\mathrm{oc}} K_{\mathrm{oc}}\right)\right)$ where $v_{\mathrm{p}}$ is the water percolation velocity in $\mathrm{m} \mathrm{s}^{-1}$ and $q_{1}$ the soil humidity (fraction of water volume to air volume).

Similarly, the chemical fraction in the leaf vegetable $C^{\text {leaf }}$ (expressed in ng kg dry weight ${ }^{-1}$ ) for a period extending from sowing to harvest can be written as follows:

Table 6

Comparison statistics for MSCE-POP/POLAIR3D-POP mean atmospheric concentrations over the entire modeling domain in the surface model layer. $\bar{c}$ is the average computed value and $\bar{m}$ the average reference (EMEP) value

\begin{tabular}{lc}
\hline Metrics & Score for BaP \\
\hline Mean concentration MSCE-POP: $\bar{m}\left(\mathrm{ng} \mathrm{m}^{-3}\right)$ & 0.25 \\
Mean concentration POLAIR3D-POP: $\bar{c}\left(\mathrm{ng} \mathrm{m}^{-3}\right)$ & 0.30 \\
Bias $\left(\mathrm{ng} \mathrm{m}^{-3}\right): \overline{m-c}\left(\mathrm{ng} \mathrm{m}^{-3}\right)$ & -0.04 \\
Spatial correlation: $\overline{(c-\bar{c})(m-\bar{m})} /\left(\sqrt{\overline{c^{2}}-\bar{c}^{2}} \sqrt{\overline{m^{2}}-\bar{m}^{2}}\right)$ & 75.0 \\
\hline
\end{tabular}

$$
\begin{aligned}
\frac{\partial C^{\text {leaf }}}{\partial t}= & \frac{a^{\text {leaf }} f_{\text {veg }}}{m^{\text {leaf }}}\left(F_{\text {daer }}^{\text {leaf }}+F_{\text {dgaz }}^{\text {leaf }}+F_{\mathrm{w}}\right) \\
& -\left(k_{\text {em }}^{\text {leaf }}+k_{\text {dg }}^{\text {leaf }}\right) C^{\text {leaf }}+\frac{K_{\mathrm{c}} E t p T_{\text {scf }}}{B K p} C^{\text {sc }}
\end{aligned}
$$

where the fluxes $F_{\text {daer }}^{\text {leaf }}, F_{\text {dgaz }}^{\text {leaf }}, F_{\mathrm{W}}\left(\mathrm{ng} \mathrm{m}^{-2} \mathrm{~s}^{-1}\right)$ and the coefficients $k_{\mathrm{em}}^{\text {leaf }}$ and $k_{\mathrm{dg}}^{\text {leaf }}\left(\mathrm{s}^{-1}\right)$ are identical to those for the vegetation cover used in Polair3D (equation (8)). In equation (13), the last term represents the chemical transfer from the soil to the root system up to the leaf via a translocation process due to respiration. It depends on the cultural coefficient $K_{\mathrm{c}}=0.9$ (Soltner, 1994) that weights the potential evapotranspiration Etp $\left(\mathrm{m} \mathrm{s}^{-1}\right)$ with the land coverage, the above-ground biomass of the vegetable (B) in dry weight $\mathrm{kg} \mathrm{m}^{-2}$, the partition coefficient between the solid and dissolved POP phases $\left(K_{\mathrm{p}}\right.$ in $\left.\mathrm{m}^{3} \mathrm{~kg}^{-1}\right)$ and a translocation factor $\left(T_{\mathrm{scf}}\right)$. This last factor is related to the octanol/water partition coefficient of the chemical based on the relationship of Briggs et al. (1982) given for a specific grass type: $T_{\mathrm{scf}}=0.784 \mathrm{exp}-((\log$ $\left.\left.K_{\text {ow }}-1.78\right)^{2} / 2.44\right)$.

One must note that in many modeling studies the chemical concentration in soil is assumed to be constant; thus, our approach with a time-dependent chemical concentration calculated from the atmospheric deposition and soil fate and transport of chemicals differs from previous work. This model was applied to study the contamination of leaf vegetables in a region of Southeastern France, the Bouches-du-Rhône department (subdivision of France administrated by a prefect) in the Provence-Alpes-Côte d'Azur (PACA) Region. Simulation results are provided below.

\subsection{Atmospheric loading}

As we want to have a general approach applicable to different pollutants and compartments for food contamination, it will be useful to conduct long-term multi-media simulations and this 


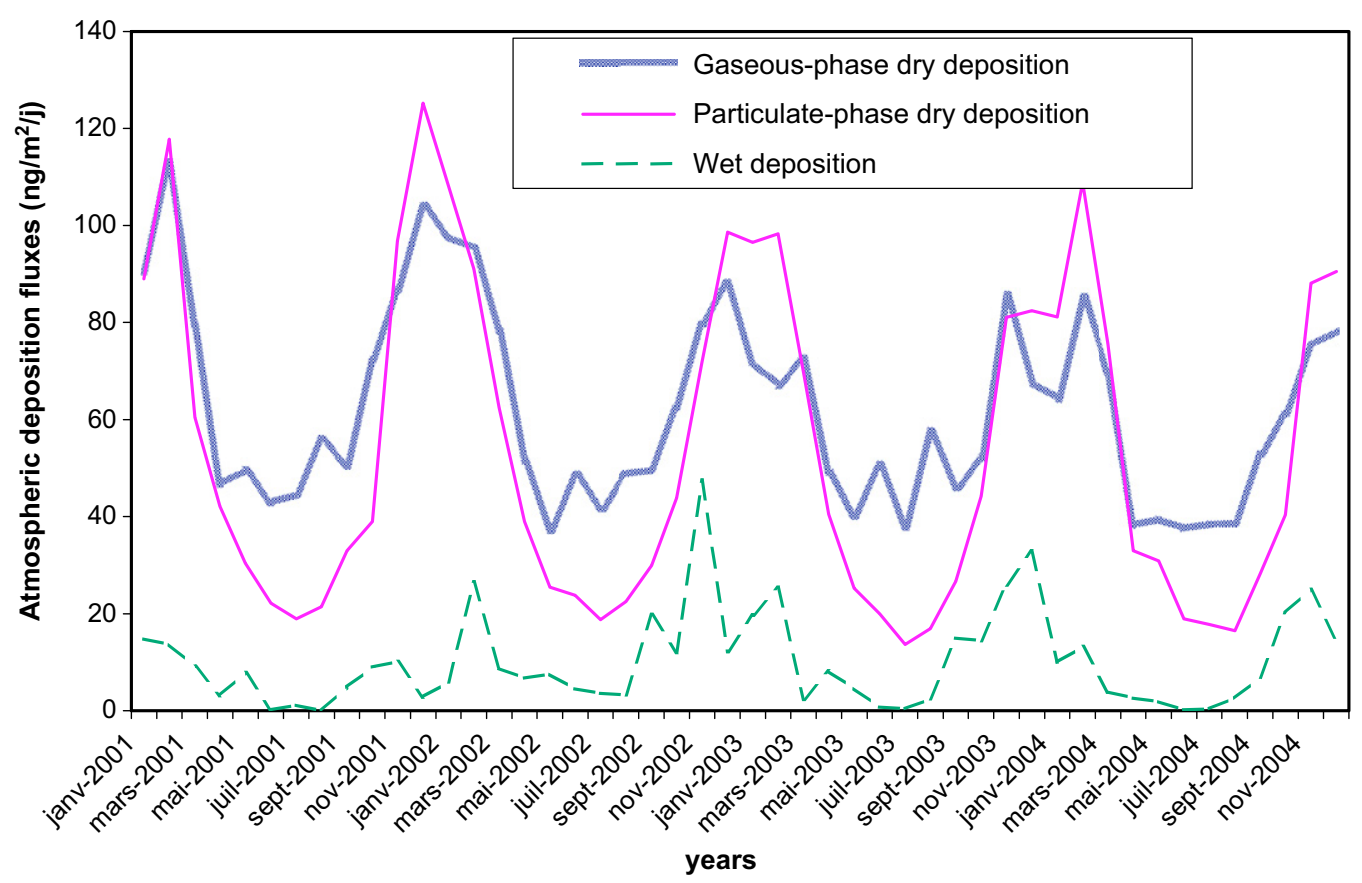

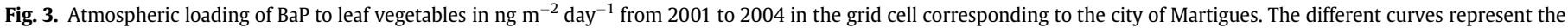
net flux for gas dry deposition (dry deposition - re-emission), the dry deposition for particles and the wet deposition for both gas and particles.

approach implies that the atmospheric simulations must be off line. To that end, the following approach was used.

The atmospheric simulations were conducted with Polair3D/ Polyphemus using available emission inventories for four consecutive years (2001-2004) in order to include some inter-annual variability in the meteorology. Next, simulations were conducted for 10 years for the cultivated land over the French Bouches-duRhône department; this area is characterized by important industrial activities as well as a dense agricultural zone that covers about $40 \%$ of the area.

Modeled atmospheric loading to leaf vegetables for the four simulated meteorological years is shown in Fig. 3 for BaP. These loading amounts are related to the particulate-phase dry deposition fluxes, the net exchange fluxes of the gaseous chemical fraction, which result from the difference between dry deposition and reemission, and the wet deposition fluxes associated with precipitation. Overall, over the four modeled years, wet deposition is significantly less than total dry deposition (i.e., both particulate and gas-phase dry deposition). Particulate-phase dry deposition is slightly greater than gas-phase dry deposition because atmospheric $\mathrm{BaP}$ is predominantly in the particulate phase over the PACA region in our model. The seasonal variability of the emissions of BaP appears in the deposition fluxes. A sensitivity test that was conducted with our model to estimate the relative fractions of local (i.e., from the sources within the department) and European emissions contaminating vegetables within the department showed that local emissions dominated for BaP (by a factor of 10, Quéguiner et al., 2009). The contribution of local emissions resulted mostly from a large fraction of particulate-phase

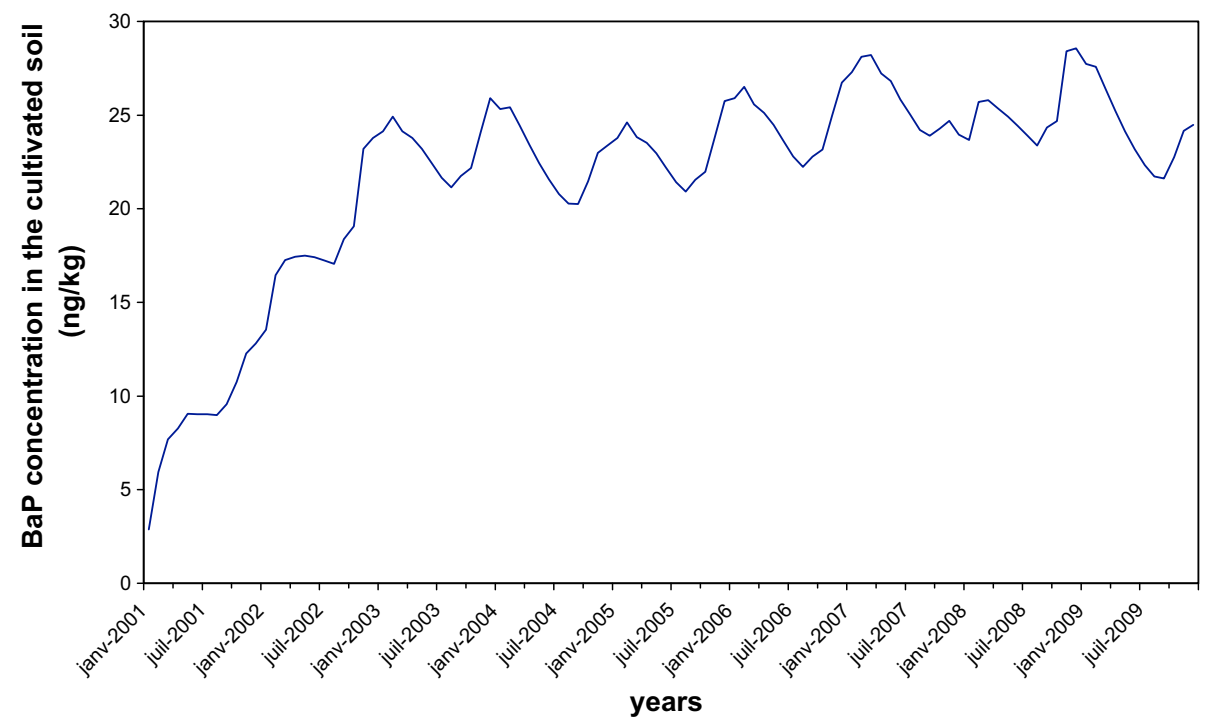

Fig. 4. Evolution of the modeled BaP concentrations in soil over 10 years in the Martigues region. 


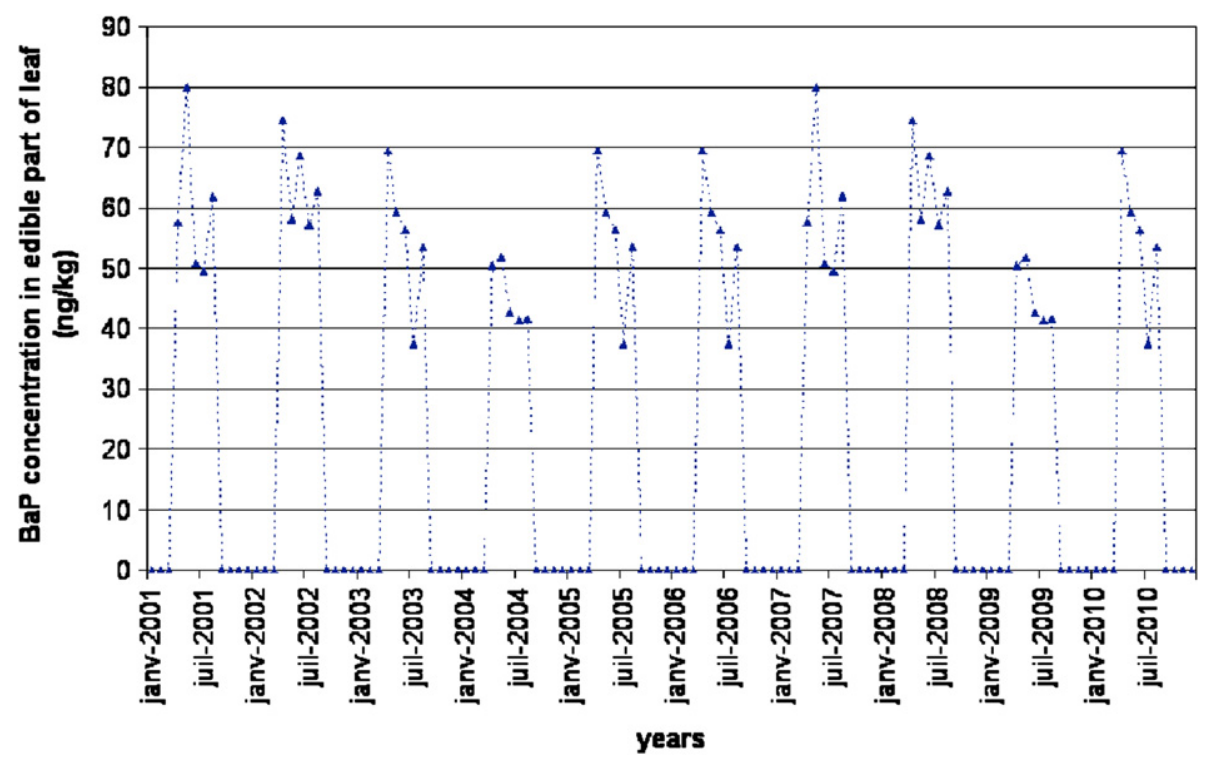

Fig. 5. Modeled BaP concentrations (ng dry weight $\mathrm{kg}^{-1}$ ) in leaf vegetables each month from germination date at harvest dates over 10 years in the Martigues region.

emissions compared to gas-phase emissions, with the former depositing faster than the latter.

\subsection{Pollution of soil and vegetation in the Bouches-du-Rhône department}

The model simulations were conducted over a 10 -year period using the atmospheric deposition output from the atmospheric model as monthly input to the soil model, with a sequence of random meteorological years selected among 2001 through 2004.

The surface concentrations in $\mathrm{BaP}$ in the cultivated soil for the grid cell of the city of Martigues are presented in Fig. 4 for 10 years. The contamination of cultivated soil results from a steady state between atmospheric inputs and losses from the soil layer, which include re-emission to the atmosphere, percolation and chemical decay.

Before steady state is achieved, the concentrations evolve as a result of the different timescales of those different processes. For $\mathrm{BaP}$, the soil concentration increases during the first years to reach steady state after three years. Note that this duration could be greater for other POPs (e.g., 13 years for PCB28). Without reliable information concerning soil concentration for model initialization, these results illustrate the need to conduct those simulations over long periods.

Contamination of leaf vegetables takes into account direct deposition from the atmosphere to the leaf and uptake from the soil via a respiratory flux that transfers chemicals through the roots toward the internal parts of the plant. Losses occur via decay within the plant, dilution during the growth phase and re-emission via volatilization. The BaP concentration in edible parts of leaf vegetable over 10 simulation years is presented in Fig. 5 .

In Fig. 5, there is no increasing trend over the long term. For BaP and leaf vegetables, the transfer from the soil via the root system is highly negligible, transfer from soil to plant: $\sim 10^{-9} \mathrm{ng}(\mathrm{kg} \text { day })^{-1}$ deposition from air to plant: $\sim 10 \mathrm{ng}(\mathrm{kg} \text { day })^{-1}$. This is due to the very low value for $T_{\mathrm{scf}}$ that gives no impact on leaf contamination even if the soil concentration is multiplied by a factor 1000. A test simulation with $T_{\mathrm{scf}}=0$ gives no change in the results. The BaP concentration in edible parts of leaf vegetable depends primarily on direct air deposition, which varies with meteorological conditions. At each harvest, the concentration varies from 40 to
$62 \mathrm{ng} \mathrm{kg}$ dry weight ${ }^{-1}$ depending on meteorological year. These results are consistent with those obtained by others: Wild and Jones $(1991,1992)$ for PAH and Nakajima et al. (1995) for BaP show that chemical concentrations in the leaf are strongly correlated to the total concentrations of atmospheric particulate matter. Other results obtained for spruce needles are similar (Umlauf and McLachlan, 1994). Beside this qualitative comparison, there are few data available for this area to quantitatively evaluate the results presented here. Nevertheless, the average BaP concentrations in vegetable, which are $0.05 \mu \mathrm{g} \mathrm{kg}^{-1}$, are commensurate with those measured in 2000 in the United Kingdom in green vegetables, potatoes, fruits and other plants where the measured concentrations did not exceed $0.04 \mu \mathrm{g} \mathrm{kg}^{-1}$ (Food Standards Agency, 2002). A better model evaluation could be conducted if measurements were available for leaf vegetables from the PACA Region.

\section{Conclusion and perspectives}

A modeling approach was presented to quantify the atmospheric contribution to contamination of cultivated soil and vegetation. This modeling approach was developed for persistent organic pollutants and some results were presented for BaP. For BaP and leaf vegetables this contamination depends primarily on direct atmospheric deposition without chemical transfer from the soil to the plant. Different results could be obtained for fruits or other chemicals such as heavy metals, as the contribution due to root uptake can then be important (Quéguiner et al., 2009).

In general, the advantage of this modeling approach is that the major transfer processes across and within the various media are taken into account, so that emission scenarios and source apportionment studies can be performed.

Clearly, this work is a first step and the results need to be confirmed with other applications. Regarding the atmospheric aspect, it would be useful to have a more complete database to evaluate the model. The POPCYCLING-Baltic project may provide useful data over the Baltic Sea in that respect.

Regarding the contamination of vegetation, besides obtaining data for model evaluation, it would be useful to account for the uncertainties associated with the various modeling steps using probability distribution functions (pdf). This work used the same modeling framework as that used for lead and cadmium by 
Quéguiner et al. (2009). Thus, identifying the pdf of the various transfer constants could lead to a probabilistic analysis of the POP concentrations in leaf vegetables. Furthermore, ensemble modeling could be conducted for atmospheric deposition of POPs in a manner similar to the modeling done for example for atmospheric ozone concentrations (Mallet et al., 2009).

This work only addressed the atmospheric contribution and further work could also take into account other inputs to cultivated soils such as fertilizer inputs, land disposal and irrigation. Nevertheless, this work is a stepping stone for future studies on the quantitative assessment of produce contamination and the associated human health risks. European projects such as HEIMTSA and 2FUN aim to treat pollution in an integrated modeling framework from emission sources to human exposure and health risk. This work provides a practical example of such a modeling approach.

\section{Acknowledgments}

The authors would like to thank Christian Seigneur for his useful comments on the manuscript.

\section{References}

AMAP, 1998. Assessment Report: Artic Pollution Issues. Artic Monitoring and Assessment Program, Oslo, Norway.

Atkinson, R., Guicherit, R., Hites, R.A., Palm, W.-U., Seiber, J.N., de Voogt, P., 1999. Transformations of pesticides in the atmosphere: a state of the art. Water Air and Soil Pollution 115, 219-243.

Briggs, G.G., Bromilow, R.H., Evens, A.A., 1982. Relationships between lipophilicity and root uptake and translocation of non-ionized chemicals by barley. Pesticide Science $13,495-504$.

Brook, J.R., Zhang, L., Di-Givanni, F., Padro, J., 1999. Description and evaluation of a model of deposition velocities for routine estimate of air pollutant dry deposition over North America. Part I: model development. Atmospheric Environment 33, 5037-5051.

Brubaker, W.W., Hites, R.A., 1998. OH reaction kinetics of gas-phase $\alpha$ - and $\gamma$-hexachlorocyclohexane and hexachlorobenzene. Environmental Science and Technology 32, 766-769.

Chen, J., Quan, X., Yan, Y., Peijnenburg, W.J.G.M., 2001. Quantitative structure-property relationship studies on the direct photolysis of selected polycyclic aromatic hydrocarbons in atmospheric aerosols. Chemosphere 42, 263-270.

Ciffroy, P., Siclet, F., Damois, C., Luck, M., 2006. A dynamic model for assessing radiological consequences of tritium routinely released in rivers: application to the Loire river. Journal of Environmental Radioactivity 90, 110-139.

Constantinou, E., Seigneur, C., 1993. A mathematical model for multimedia health risk assessment. Environmental Software 8, 231-246.

EMEP/MSC-W. 1996. Transboundary air pollution in Europe. Part 1: Estimated Dispersion of Acidifying Agents and Near Surface Ozone. Technical Report 1/ 1996. EMEP/MSC-W.

EPA, 1998. Human Health Risk Assessment Protocol for Hazardous Waste Combustion Facilities. U.S. Environmental Protection Agency, Office of Solid Waste. http://www.epa.gov/Arkansas/6pd/rcra_c/protocol.

Falconer, R.L., Harner, T., 2000. Comparison of octanol-air partition coefficient and liquid-phase vapor pressure as descriptors for particle/gas partitioning using laboratory and field data for PCBs and PCNs. Atmospheric Environment 34, 4043-4046.

Food Standards Agency, 2002. PAHs in the UK Diet Study Samples. Food Survey Information Sheet Number.

Gusev, A., Mantseva, E., Shatalov, V., Razovovska, O., Vulykh, N., 2005. Regional Multi-compartment Model MSCE-POP. Technical Report 5/2005. EMEP/MSC-E.

Hansen, K.M., Christensen, J.H., Brandt, J., Frohn, L.M., Geels, C., 2004. Modelling atmospheric transport of $\alpha$-hexachlorocyclohexane in the northern hemisphere using a 3-D dynamical model: DEHM-POP. Atmospheric Chemistry and Physics 4, 1125-1137.

Hincley, D.A., Bidleman, T.F., Foreman, W.T., 1990. Determination of vapor pressures for non-polar and semipolar organic compounds from gas chromatographic retention data. Journal of Chemical Engineering 35 (3), 232-237.

Horstmann, M., McLachlan, M.S., 1998. Atmospheric deposition of semi-volatile organic compounds to two forest canopies. Atmospheric Environment 32, 1799-1809.

Hulscher, M.F., Van Der Velde, L.E., Bruggeman, W.A., 1992. Temperature dependence of Henry's law constants for selected chlorobenzenes, polychlorinated biphenyls and polycyclic aromatic hydrocarbons. Environmental Toxicology and Chemistry 11, 1595-1603.

Jones, K.C., de Voogt, P., 1999. Persistent organic pollutants (POPs): state of the science. Environmental Pollution 100, 209-221.
Junge, C.E., 1977. In: Suffet, I.H. (Ed.), Fate of Pollutants in the Air and Water Environment - Part I. Basic Considerations about Trace Constituent in the Atmosphere is Related to the Fate of Global Pollutant. Wiley-Interscience.

Jury, W.A., Spencer, W.F., Farmer, W.J., 1983. Behaviour assessment model for trace organics in soil. I. Model description. Journal of Environmental Quality 12, 558-564.

Legind, C., Trapp, S., 2009. Modeling the exposure of children and adults via diet to chemicals in the environment with crop-specific models. Environmental Pollution 157, 778-785.

Mackay, D., Paterson, S., 1991. Evaluating the multimedia fate of organic chemicals a level III fugacity method. Environmental Science and Technology 25, 427-436.

Mackay, D., Shiu, W.Y., Ma, K.C., 1992. Illustrated handbook of physical-chemical properties and environmental fate for organic chemicals. In: Polynuclear Aromatic Hydrocarbons, Polychlorinated Dioxins and Dibenzofuran's, V.2. Lewis Publishers.

Mallet, V., Stoltz, G., Mauricette, B., 2009. Ozone ensemble forecast with machine learning algorithms. Journal of Geophysical Research 114, D05307. doi:10.1029/ 2008JD009978. 2009.

Mallet, V., Quélo, D., Sportisse, B., De Biasi, M., Ahmad, M., Debry, E., Korssakissok, I. Wu, L., Roustan, Y., Sartelet, K., Tombette, H., Foudhil, H., 2007. Technical note: the air quality modeling system Polyphemus. Atmospheric Chemistry and Physics Discussion 7, 6459-6486.

McLachlan, M.S., Welsch-Pausch, K., Tolls, J., 1995. Field validation of a model of uptake of gaseous SOC in Lolium multiflorum (rye grass). Environmental Science and Technology 29, 1998-2004.

Nakajima, D., Yoshida, Y., Suzuki, J., Suzuki, S., 1995. Seasonal changes in the concentration of polycyclic aromatic hydrocarbons in azalea leaves and relationship to atmospheric concentration. Chemosphere 30, 409-418.

Quéguiner, S., 2008. Modélisation couplée atmosphere-sol-végétation pour l'évaluation de l'impact des rejets atmosphériques des métaux lourds et des Polluants Organiques Persistants à l'échelle Européenne, Ph.D. thesis, École Nationale des Ponts et Chaussées, 239 pp.

Quéguiner, S., Ciffroy, P., Roustan, Y., Musson Genon, L., 2009. Multimedia modelling of the exposure to cadmium and lead released in the atmosphere - application to industrial releases in a Mediterranean region and uncertainty sensitivity analysis. Water Air and Soil Pollution 198, 199-217.

Riederer, M., 1990. Estimating partitioning and transport of organic chemicals in the foliage/atmosphere system: discussion of a fugacity-based moel. Environmental Science and Technology 24, 829-837.

Roselle, S.J., Binkowski, F.S., 1999. Cloud dynamics and chemistry, science algorithms of the EPA Models-3. Tech. Rep.EPA/600/R-99/030. EPA.

Roustan, Y., 2005. Modélisation de la dispersion atmosphérique du mercure, du plomb et du cadmium à l'échelle européenne. Ph.D. thesis, École Nationale des Ponts et Chaussées, $167 \mathrm{pp}$.

Ruijgrok, W., Tieben, H., Eisinga, P., 1997. The dry deposition of particles to a forest canopy: a comparison of model and experimental results. Atmospheric Environment 31, 399-415.

Sartelet, K., Debry, E., Fahaey, K., Tombette, M., Roustan, Y., Sportisse, B., 2007 Simulation of aerosols and gas phase species over Europe with the Polyphemus system, part I: model-to-data comparison for year 2001. Atmospheric Environment 41 (29), 6116-6131.

Seth, R., Mackay, D., Muncke, J., 1999. Estimating the organic carbon partition coefficient and its variability for hydrophobic chemicals. Environmental Science and Technology 33, 2390-2394.

Shatalov, V., Mantseva, E., Baart, A., Bartlett, P., Breivik, K., Christensen, J.H., Dutchak, S., Gong, S., Gusev, A., Hansen, K.M., Hollander, A., Huang, P., Hungerbäuhler, K. Jones, K.C., Petersen, G., Roemer, M., Sheringer, M., Stocker, J., Suzuki, N., Sweetman, A.J., Van de Meent, D., Wegmann, F., 2005. POP model intercomparison study, stage II. Comparison of mass balance estimates and sensitivity studies. Tech. Rep. 4/2005. EMEP/MSC-E.

Schwarzenbach, R.P., Gschwend, P.M., Imboden, D.M., 1993. Environmental Organic Chemistry. J. Wiley and Sons.

Severinsen, R.P., Jager, T., 1998. Modelling the influence of terrestrial vegetation on the environmental fate of xenobiotics. Chemosphere 37, 41-62.

Soltner, D., 1994. Les bases de la production végétale. Le sol. Collections Sciences et Techniques agricoles.

Strand, A., Hov, O., 1996. A model strategy for the simulation of chlorinated hydrocarbon distributions in the global environment. Water Air and Soil Pollution 86, 283-316.

Thomas, J.F., Sweetman, A.J., Ockenden, W.A., Mackay, D., Jones, K.C., 1998. Air-pasture transfer of PCBs. Environmental Science and Technology 32, 936-942.

Tsyro, S., Erdman, L., 2000. Parameterization of Aerosol Deposition Processes in EMEP MSC-E and MSC-W Transport Models. Tech. Rep., 7/2000, EMEP MSC-W.

Umlauf, G., McLachlan, M., 1994. Deposition of semi-volatile organic compounds to spruce needles. I. Calculation of dry and wet fluxes. Environmental Science and Pollution Research 1, 146-150.

Van Jaarsveld, J.A., Van pul, W.A.J., De Leeuw, F.A.A.M., 1997. Modelling transport and deposition of persistent organic pollutants in the European region. Atmospheric Environment 31, 1011-1024.

Wania, F., Mackay, D., 1993. Global fractionation and cold condensation of low volatility organochlorine compounds in polar region. Ambio 22-1, 10-18.

Wania, F., Mackay, D., 1996. Tracking the distribution of persistent organic pollutants. Environmental Science and Technology 30, 390-396.

Wania, F., MaLachlan, M.S., 2001. Estimating the influence on forests on the overall fate of semi-volatile organic compounds using a multimedia fate model. Environmental Pollution 102, 3-23. 
Wegmann, F., Scheringer, M., Möller, M., Hungerbûhler, K., 2004. Influence of vegetation on the environmental partitioning of DDT in two global models. Environmental Science and Technology 38, 1505-1512.

Wesely, M.L., Cook, D.R., Hart, R.L., Speer, R.E., 1985. Measurements and parameterization of particulate sulfur dry deposition over grass. Journal of Geophysical Research 90, 2131-2143.
Whitby, K.T., 1978. The physical characteristics of sulphur aerosols. Atmospheric Environment 12, 135-159.

Wild, S.R., Jones, K.C., 1991. Studies on the polynuclear aromatic hydrocarbon content of carrots (daucus carota). Chemosphere 23, 243-251.

Wild, S.R., Jones, K.C., 1992. Polynuclear aromatic hydrocarbon uptake by carrots in sludge-amended soil. Journal of Environmental Analytical Chemistry 21, 217-225. 